\title{
1,3-Dipolar cycloaddition reactions of azomethine ylides with aromatic dipolarophiles
}

\author{
John H. Ryan \\ CSIRO Manufacturing Flagship, Ian Wark Laboratory, Bayview Avenue, Clayton, VIC 3168, \\ Australia \\ E-mail:jack.ryan@csiro.au
}

DOI: $\underline{\text { http://dx.doi.org/10.3998/ark.5550190.0016.107 }}$

\begin{abstract}
The 1,3-dipolar cycloadditions of azomethine ylides to aromatic dipolarophiles are reviewed and discussed. The reaction proceeds with stabilized and non-stabilized azomethine ylides, although most studies have been with non-stabilized systems. While simple benzene derivatives do not readily undergo such 1,3-dipolar cycloaddition reactions, the dipolarophilic character of benzene emerges when the benzenoid nucleus is embedded within a polycyclic aromatic hydrocarbon, tethered with the azomethine ylide (an intramolecular process) or substituted with highly electron withdrawing nitro groups. Heteroaromatic systems display similar tendencies towards such cycloaddition processes. The review closes with a consideration of the mechanism of the reactions.
\end{abstract}

Keywords: Dearomatization, 1,3-dipolar cycloaddition, azomethine ylide, aromatic dipolarophiles, intramolecular cycloaddition, nitrobenzenes

\section{Table of Contents}

1. Introduction

2. 1,3-Dipolar Cycloaddition Reactions of a Stabilized Azomethine Ylide with Polycyclic Aromatic Dipolarophiles

3. Intramolecular Reactions of Stabilized Azomethine Ylides with Aromatic and Heteroaromatic Dipolarophiles

4. Reactions of Non-stabilized Azomethine Ylides with Nitro-substituted Heteroaromatic Dipolarophiles

5. Reactions of Non-stabilized Azomethine Ylides with Nitro-substituted Benzenoid Aromatic Dipolarophiles

6. Mechanism 
7. Acknowledgements

8. References

\section{Introduction}

A large and structurally diverse range of aromatic compounds are available for use as starting materials in organic synthesis and ultimately find use in numerous fine chemical, pharmaceutical and agrochemical products. As a result, much endeavor has been targeted at methods for functionalization of aromatic compounds. These methods include processes resulting in aromatic carbon-hydrogen functionalization, ${ }^{1-5}$ and processes resulting in loss of the aromatic system, i.e. 'dearomatization' processes. ${ }^{6,7}$ Well-studied examples of dearomatization processes include Birch reduction, ${ }^{8-11}$ enzymatic cis-dihydroxylation, ${ }^{12-14}$ oxidative dearomatization of phenols, ${ }^{15-21}$ enzymatic benzene reductions, ${ }^{22}$ transition-metal complexing dearomatizations, ${ }^{23-25}$ nucleophilic dearomatization processes ${ }^{26-31}$ and catalytic hydrogenation. ${ }^{32-35}$ An alternative dearomatization process would involve a [4+2] or [3+2] cycloaddition reaction of a diene or 1,3-dipole with an aromatic carbon-carbon double bond. ${ }^{36-40} \mathrm{~A}$ manifestation of this concept is the 1,3-dipolar cycloaddition reaction of an azomethine ylide $\mathbf{1}$ with a benzenoid aromatic system $\mathbf{2}$ that would give an isoindole derivative 3 (Scheme 1). Azomethine ylides, which contain four electrons distributed over the $\pi$ orbitals of a $\mathrm{C}-\mathrm{N}-\mathrm{C}$ group, are examples of bent allyl anion-type 1,3dipoles. ${ }^{41}$ The ylides can be classified as non-stabilized (where $\mathrm{R}^{1}, \mathrm{R}^{2}$ and $\mathrm{R}^{3}=\mathrm{H}$ or alkyl) or stabilized either by electron-withdrawing/electron-donating groups at the appropriate termini of the ylide or by $\mathrm{N}$-metalation. ${ }^{41}$ Azomethine ylides are mostly generated in situ due to their high reactivity and/or transient existence; however, in some cases, stabilized azomethine ylides have been isolated. ${ }^{42-44}$ The isoindole framework is found within a large range of natural products and frequently features in bioactive natural products, synthetic agrochemicals, pharmaceuticals and dyes. $^{45-47}$ Although simple and elegant in concept, azomethine ylide 1,3-dipolar cycloaddition dearomatization processes have received only sporadic attention until recently.

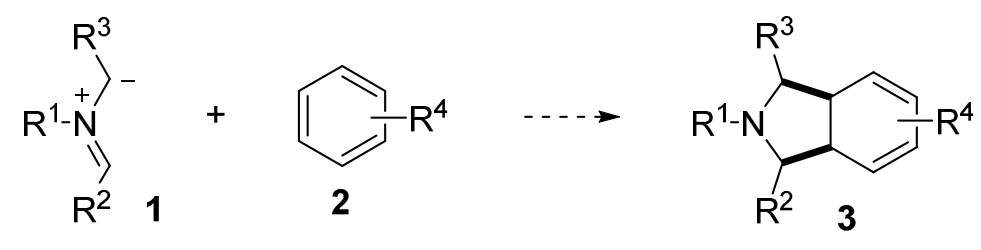

\section{Scheme 1}


<smiles>CN[C@H]1C[C@@H]2O[C@@](C)([C@H]1OC)n1c3ccccc3c3c4c(c5c6ccccc6n2c5c31)CNC4=O</smiles><smiles>O=C(O)C(CC(=O)N1C[C@H]2CCCC[C@H]2C1)Cc1ccccc1</smiles><smiles>Nc1cccc2c1CN(C1CCC(=O)NC1=O)C2=O</smiles><smiles></smiles>

Examples of isoindole-containing natural products, pharmaceuticals and dyes: (+)-staurosporine 4 (indolocarbazole alkaloid), ${ }^{45}$ mitiglinide 5 (type 2 diabetes), ${ }^{46}$ lenalidomide 6 (anticancer, multiple myeloma), ${ }^{47}$ and Pigment Yellow 1397 (dye). ${ }^{45}$

Here is presented a comprehensive review of the literature associated with the 1,3-dipolar cycloaddition reactions of azomethine ylides with benzo- and heteroaromatic systems until the end of 2013. While outside the scope of this review, it is noted that the cycloaddition of azomethine ylides to $\mathrm{C}_{60}$, graphite and related materials is considered an excellent way to functionalize these materials. ${ }^{48-52}$

\section{1,3-Dipolar Cycloaddition Reactions of a Stabilized Azomethine Ylide with Polycyclic Aromatic Dipolarophiles}

In 1971, Huisgen and Scheer reported the reactions of polycyclic aromatic compounds with a stabilized azomethine ylide, revealing for the first time that, "Only few 1,3-dipoles equal ozone in its ability to attack the aromatic bond. The azomethine ylide (10) is one of them". ${ }^{53}$ The azomethine ylide $\mathbf{1 0}$ was generated by thermal electrocyclic ring-opening of aziridine $\mathbf{8}$ which gives exo-exo azomethine ylide 9 which then isomerises to the more reactive endo-exo dipole 10 (Scheme 2). The heating of aziridine 8 with an excess of phenanthrene $\mathbf{1 1}$ at $100{ }^{\circ} \mathrm{C}$ for $24 \mathrm{~h}$ afforded a single cycloadduct 12 isolated in 36\% yield (Scheme 3). The stereochemistry of product $\mathbf{1 2}$ was taken as evidence that azomethine ylide $\mathbf{1 0}$ was the reactive species.

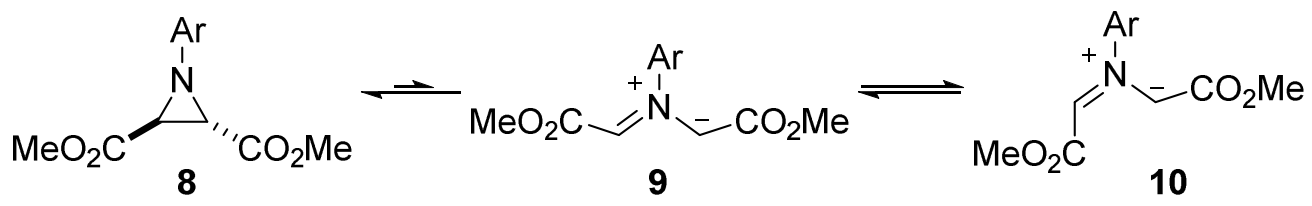
$\mathrm{Ar}=4$-methoxyphenyl

\section{Scheme 2}




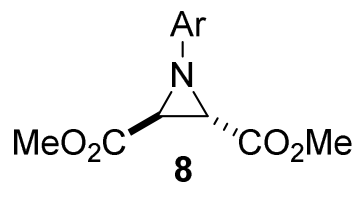

$\mathrm{Ar}=4$-methoxyphenyl
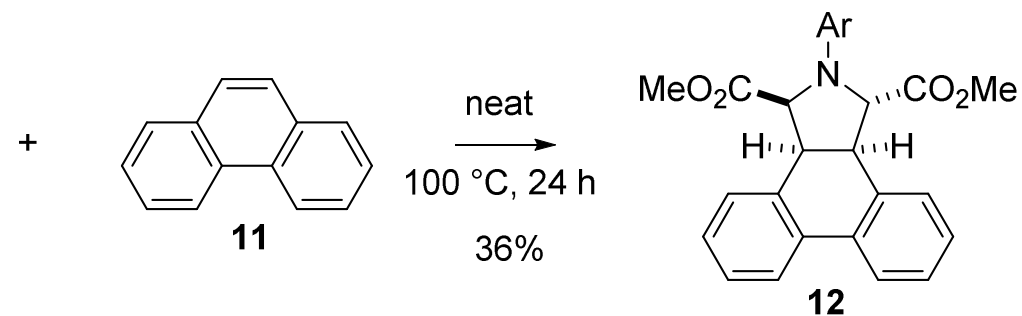

\section{Scheme 3}

The cycloaddition reactions of linear polycyclic aromatic systems were also explored. ${ }^{53}$ The reaction of aziridine 8 with excess anthracene in refluxing chlorobenzene for $24 \mathrm{~h}$, led to a mono adduct 13, isolated in $8 \%$ yield, and two bis adducts, assigned $\mathbf{1 4}$ and $\mathbf{1 5}$, isolated in $22 \%$ and $40 \%$ yield, respectively. While various isomers were considered, the two isomeric anti bis adduct structures 14 and 15 (endo/exo isomers) were preferred based on spectroscopic analysis, with compound 14 exhibiting spectra consistent with a two-fold axis of symmetry whereas $\mathbf{1 5}$ exhibited spectra consistent with a lack of such symmetry elements. The formation of bis adducts 14 and 15 was rationalized by the mono adduct 13 having a styrene-like olefin whose dipolarophilic character far exceeds that of the aromatic bonds of the starting material, anthracene. Therefore, most of mono adduct $\mathbf{1 3}$ took up an extra molecule of the azomethine ylide 10 to produce the bis adducts, despite there being an excess of anthracene. For the reaction of aziridine $\mathbf{8}$ with naphthalene at $120{ }^{\circ} \mathrm{C}$ for $24 \mathrm{~h}$, only the two anti bis adducts $\mathbf{1 6}$ and $\mathbf{1 7}$ were isolated, in $38 \%$ yield. The structures were assigned similarly to the bis adducts from anthracene, with 16 exhibiting a symmetry element.<smiles>COC(=O)[C@H]1[C@H]2C=Cc3cc4ccccc4cc3[C@H]2[C@H]1C(=O)OC</smiles>

13

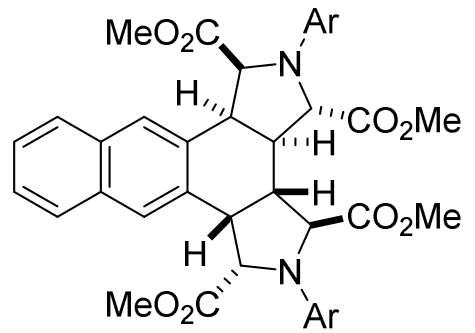

14

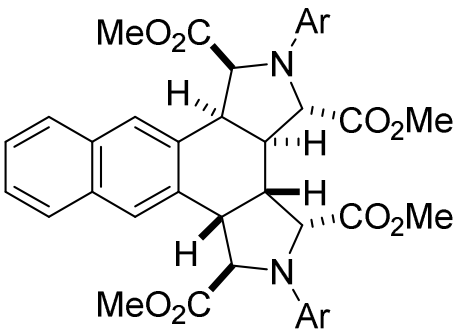

15

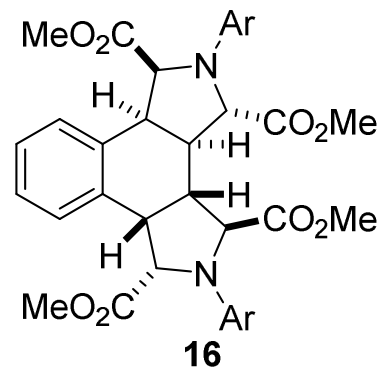

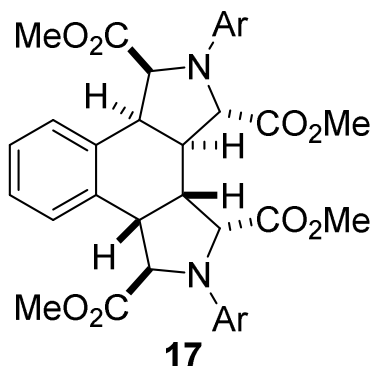

$\mathrm{Ar}=4-$ methoxyphenyl 


\section{Intramolecular Reactions of Stabilized Azomethine Ylides with Aromatic and Heteroaromatic Dipolarophiles}

In 1992 Heathcock, et al. reported a surprising side reaction involving 1,3-dipolar cycloaddition of a doubly-stabilized azomethine ylide to an unactivated aromatic dipolarophile, whilst studying intramolecular cycloadditions of azomethine ylides tethered with unactivated olefinic dipolarophiles. ${ }^{54}$ Thus, thermolysis of aziridine $\mathbf{1 8}$ under flash vacuum pyrolysis conditions provided the expected lactam 20 as a single diastereoisomer in $78 \%$ yield along with $4 \%$ of a minor sideproduct 21 (Scheme 4). It was proposed that the reaction proceeded via electrocyclic ringopening of the aziridine 18 to afford doubly stabilized azomethine ylide $\mathbf{1 9}$ which added as expected to the pendant olefin to produce bicyclic lactam $\mathbf{2 0}$ or to the pendant phenyl group to product tricyclic lactam 21.

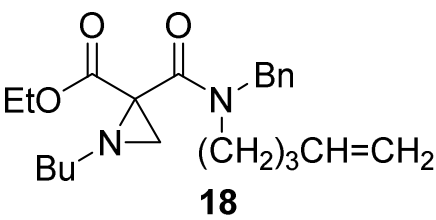

18

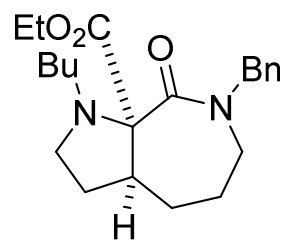

$20(78 \%)$

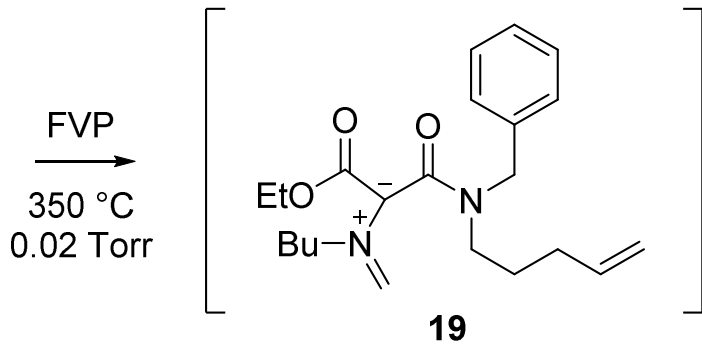

19

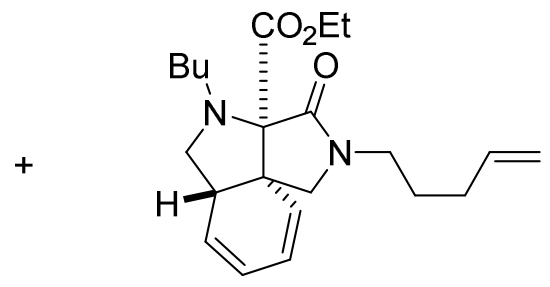

$21(4 \%)$

\section{Scheme 4}

Heathcock et al. recognized the potential utility of this side reaction as it generated a highly functionalized tricyclic compound containing three contiguous stereo-centres (two of which are quaternary) in a stereo-controlled manner. ${ }^{54}$ They sought to increase the yield of the addition to the phenyl group by eliminating the possibility of alkene cycloaddition and prepared a series of analogous dibenzylamides $22-27$ for pyrolysis studies (Scheme 5). Flash vacuum pyrolysis of each of the symmetrical dibenzylamides $\mathbf{2 2}-\mathbf{2 4}$ afforded the respective tricyclic product in moderate to good yields (28: 67\%, 29: 47\% and 30: 68\%). These experiments demonstrated that the intramolecular cycloaddition could proceed with unsubstituted phenyl groups and with phenyl groups substituted with electron-donating or electron-withdrawing groups. Pyrolysis of the bis(4-cyanobenzyl)amide 25 resulted in decomposition with none of the expected product obtained, pointing to a potential limitation of this methodology. 


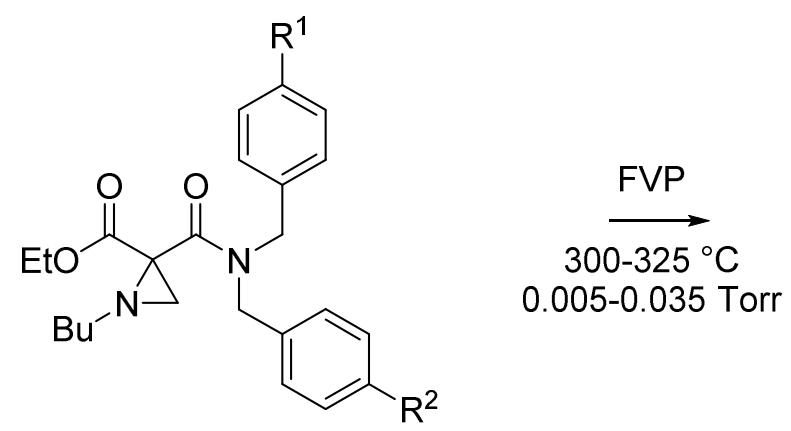

$$
\begin{aligned}
& 22 \mathrm{R}^{1}=\mathrm{R}^{2}=\mathrm{H} \\
& 23 \mathrm{R}^{1}=\mathrm{R}^{2}=\mathrm{OMe} \\
& 24 \mathrm{R}^{1}=\mathrm{R}^{2}=\mathrm{CF}_{3} \\
& 25 \mathrm{R}^{1}=\mathrm{R}^{2}=\mathrm{CN} \\
& 26 \mathrm{R}^{1}=\mathrm{H}, \mathrm{R}^{2}=\mathrm{OMe} \\
& 27 \mathrm{R}^{1}=\mathrm{H}, \mathrm{R}^{2}=\mathrm{CF}_{3}
\end{aligned}
$$

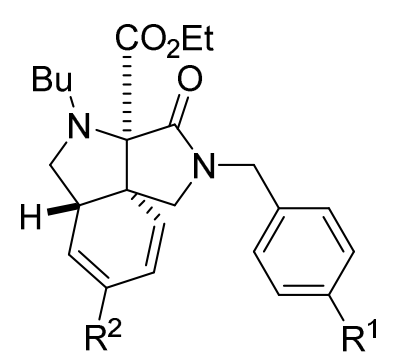

$$
\begin{aligned}
& 28 R^{1}=R^{2}=H \\
& 29 R^{1}=R^{2}=O M e \\
& 30 R^{1}=R^{2}=C F_{3} \\
& 31 R^{1}=H, R^{2}=O M e \\
& 32 R^{1}=O M e, R^{2}=H \\
& 33 R^{1}=H, R^{2}=C F_{3} \\
& 34 R^{1}=C F_{3}, R^{2}=H
\end{aligned}
$$

\section{Scheme 5}

The lower yield of dimethoxy analogue $\mathbf{2 9}$ was rationalized in terms of hydrolytic instability of the enol ether moiety and this was confirmed by a deliberate acid catalyzed hydrolysis of enol 29 affording enone $\mathbf{3 5}$ in $83 \%$ yield (Scheme 6). The stereochemistry of cycloadduct 29 was proven by reduction of the ester to an alcohol, enol hydrolysis and concomitant conjugate addition which gave tetracycle $\mathbf{3 6}$ in overall 50\% yield (Scheme 6). Such a conjugate addition process could only be achieved with the depicted ring-fusion stereochemistry.

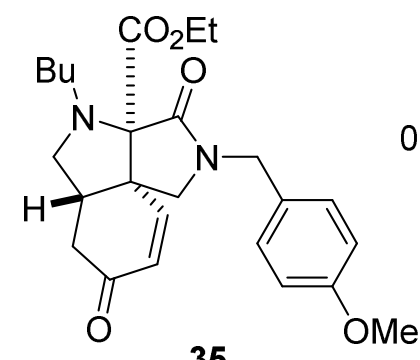

35

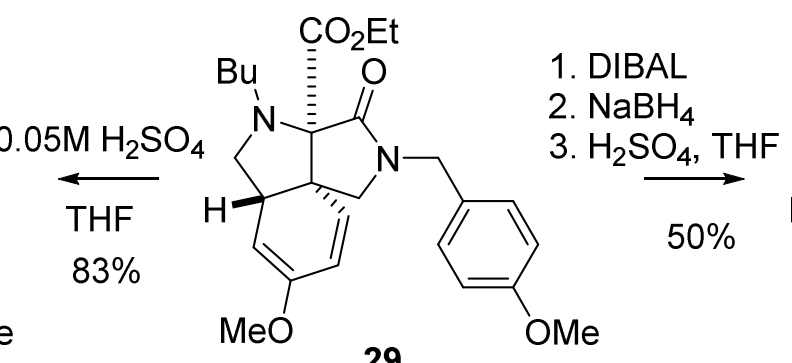

29

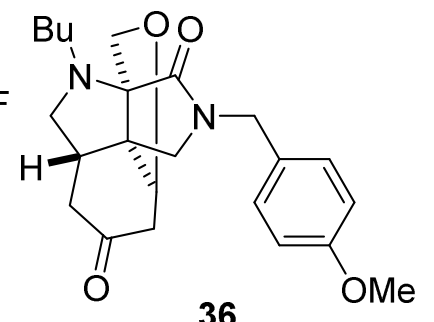

36

\section{Scheme 6}

The pyrolysis of the unsymmetrically substituted dibenzylamides provided insight into the reversibility of the cycloaddition process under flash vacuum pyrolysis conditions (Scheme 7). ${ }^{54}$ Pyrolysis of the methoxy analogue $\mathbf{2 6}$ afforded a $42 \%$ yield of a mixture of cycloadducts $\mathbf{3 1}$ and 32 in approximately a 1:1 ratio. Pyrolysis of trifluoromethyl analogue 27 afforded a $71 \%$ yield of the cycloadducts 33 and 34 in a ca. 70:30 ratio. These products were separated and then independantly subjected to the pyrolytic conditions, which resulted in the same 70:30 ratio of $\mathbf{3 3}$ 
and 34. These results demonstrate that the cycloadducts $\mathbf{3 3}$ and $\mathbf{3 4}$ isomerise via cycloreversion to the azomethine ylide $\mathbf{3 7}$ under the flash vacuum pyrolysis conditions (Scheme 7).
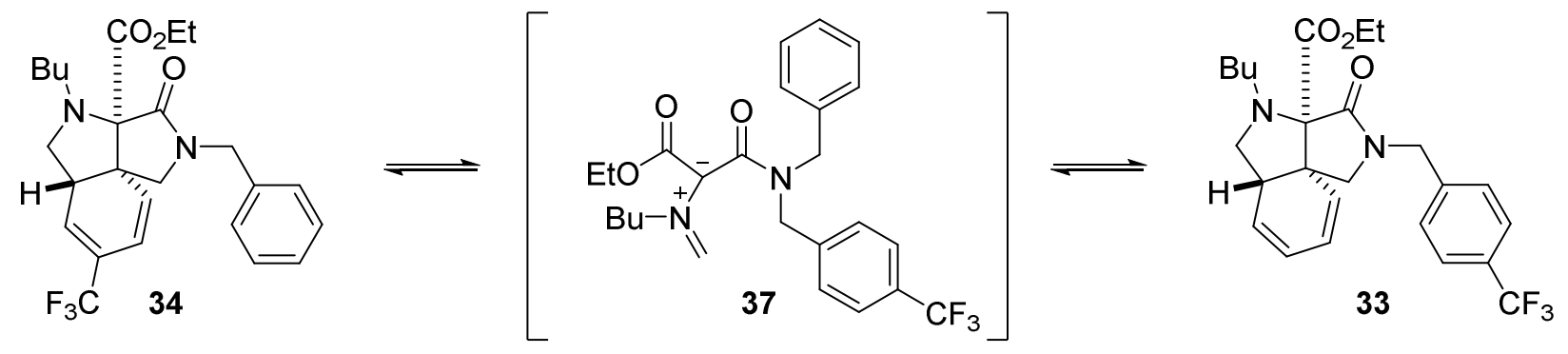

\section{Scheme 7}

While the work of Heathcock and coworkers was the first example of an addition of an azomethine ylide to an isolated benzene ring, intramolecular additions of azomethine ylides to a heteroaromatic system, i.e. furan, had been previously reported by Tsuge and coworkers. ${ }^{55,56}$ It is well known that imines of $\alpha$-amino acid esters readily tautomerize to give azomethine ylides. ${ }^{57-60}$ The imine 38 was used as a precursor of azomethine ylide $39 .^{55}$ When a solution of 38 in xylene was refluxed for $30 \mathrm{~h}$, a complex mixture resulted and the intramolecular cycloadduct $\mathbf{4 0}$ was obtained in low yield (Scheme 8).<smiles>CC(=O)C(/N=C/c1ccccc1OCc1ccco1)c1ccccc1</smiles>

38<smiles>CC(=O)[C@H](NC=Cc1ccccc1OCc1ccco1)c1ccccc1</smiles>

39

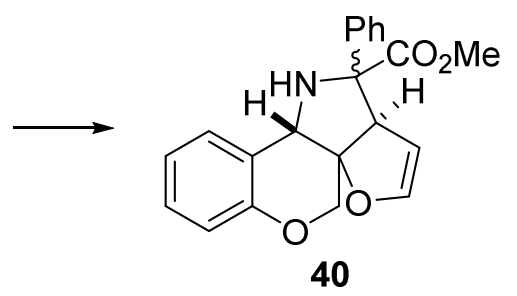

40

\section{Scheme 8}

Tsuge and coworkers obtained improved yields of intramolecular cycloadducts using a different mechanism for generating the azomethine ylide. ${ }^{56}$ 4-Isoxazolines are generally unstable and thermally rearrange to acylaziridines. ${ }^{61}$ The thermal or photochemical cleavage of aziridines is a well known source of azomethine ylides that undergo 1,3-dipolar cycloaddition reactions. ${ }^{62-}$ 64 Tsuge and coworkers found that 4-isoxazolines can be used as precursors of azomethine ylides in 1,3-dipolar cycloaddition reactions and exemplified this via intramolecular addition to a pendant furan ring. ${ }^{56}$ The reaction of $N$-methylnitrone 41a with dimethyl acetylenedicarboxylate (DMAD) in benzene resulted in the 4-isoxazoline 42a, isolated in quantitative yield. (Scheme 9) 

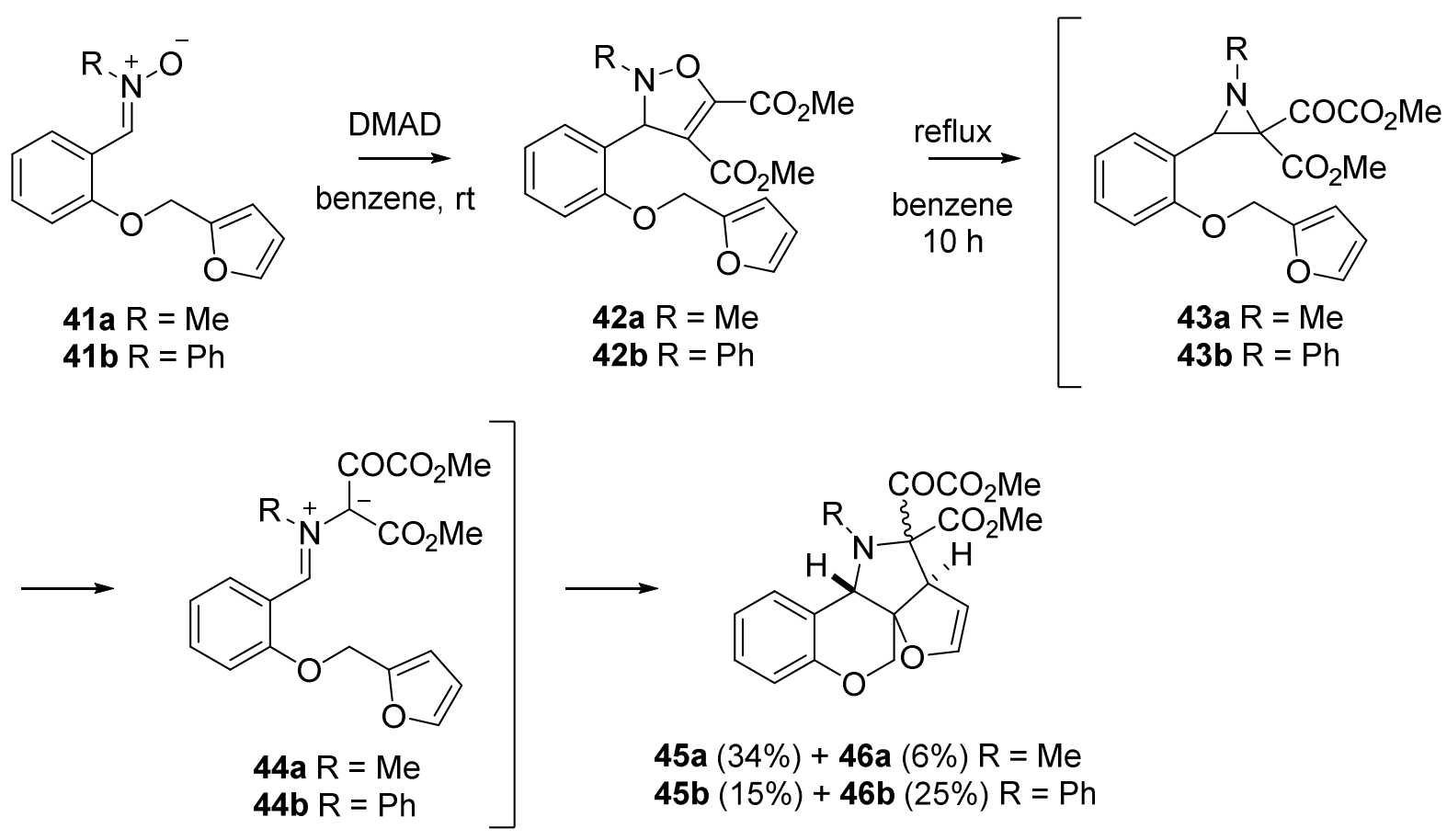

\section{Scheme 9}

Heating of 42a in refluxing benzene for $10 \mathrm{~h}$ produced, via ring-contraction to aziridine 43a then electrocyclic ring-opening to azomethine ylide $\mathbf{4 4 a}$, followed by 1,3-dipolar cycloaddition, to give a mixture of steroisomers $\mathbf{4 5 a}$ and 46a, in 34 and 6\% yield, respectively. Similarly, heating of the $N$-phenylnitrone 41b with DMAD in refluxing benzene gave the stereoisomers 45b and 46b in 15 and 25\% yield, respectively (Scheme 9).

\section{Reactions of Non-stabilized Azomethine Ylides with Nitro-substituted Heteroaromatic Dipolarophiles}

In 2007, Gribble and coworkers showed that non-stabilized azomethine ylides 49, generated by decarboxylative condensation of amino acids 47 and formaldehyde 48 (Scheme 10), ${ }^{65-67}$ reacted with the indole $\pi$-bond of 3- and 2-nitroindoles. ${ }^{68}$ For example, reaction of 3-nitroindoles $\mathbf{5 0}$ with sarcosine $47 \mathbf{a}$ or $N$-benzylglycine $\mathbf{4 7 b}$, and formaldehyde afforded moderate to high yields of the respective cycloadducts $\mathbf{5 1}$ (Scheme 11). No such reaction was observed between the azomethine ylide from sarcosine and paraformaldehyde with 1-(phenylsulfonyl)indole, 3-cyano-1(phenylsulfonyl)indole or 1-benzyl-3-nitroindole. This indicated that the presence of the electron withdrawing nitro group and an electron withdrawing protecting group on the indole nitrogen increased the dipolarophilic reactivity of the indole toward the azomethine ylide. Furthermore, the reaction of $\mathbf{5 0}\left(\mathrm{R}^{1}=\mathrm{SO}_{2} \mathrm{Ph}\right)$ with glycine and paraformaldehyde did not furnish a cycloadduct, indicating that azomethine ylides generated from secondary amino acid derivatives 
are more effective 1,3-dipoles in this case. The analogous 2-nitroindoles also underwent the cycloaddition reaction. For instance, 1-phenylsulfonyl-2-nitroindole 52 reacted with amino acid derivatives $\mathbf{4 7 a}$ and $\mathbf{4 7} \mathbf{b}$ and paraformaldehyde to give the cycloadducts 53a and 53b respectively (Scheme 12).

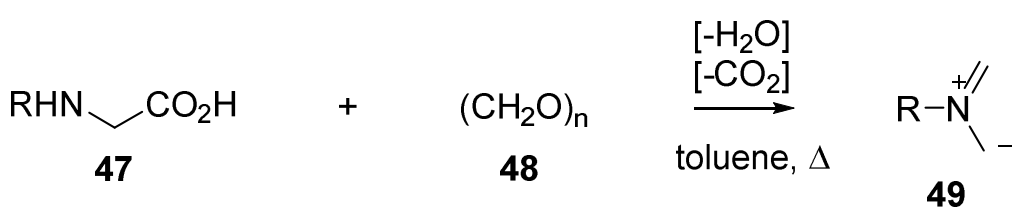

\section{Scheme 10}<smiles>[R]n1cc([N+](=O)[O-])c2ccccc21</smiles>

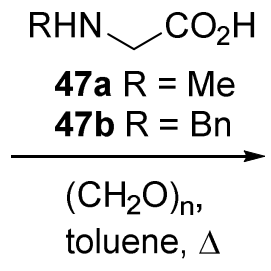<smiles>[R]N1CC2([N+](=O)[O-])CN([R])[C@@H]2c2ccccc21</smiles>

51a $\mathrm{R}^{1}=\mathrm{SO}_{2} \mathrm{Ph}, \mathrm{R}=$ Me $61 \%$

51b $\mathrm{R}^{1}=\mathrm{SO}_{2} \mathrm{Ph}, \mathrm{R}=\mathrm{Bn} 95 \%$

51c $\mathrm{R}^{1}=\mathrm{CO}_{2} \mathrm{Et}, \mathrm{R}=\mathrm{Me} 69 \%$

51d $R^{1}=\mathrm{CO}_{2}$ Et, $R=\mathrm{Bn} 96 \%$

Scheme 11<smiles>O=[N+]([O-])c1cc2ccccc2n1S(=O)(=O)c1ccccc1</smiles>

52

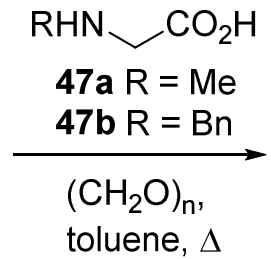

53a $\mathrm{R}^{1}=\mathrm{SO}_{2} \mathrm{Ph}, \mathrm{R}=\mathrm{Me} 86 \%$

53b $\mathrm{R}^{1}=\mathrm{SO}_{2} \mathrm{Ph}, \mathrm{R}=\mathrm{Bn} 67 \%$

\section{Scheme 12}

The potential synthetic versatility of the products was demonstrated by treatment of the cycloadduct $\mathbf{5 1 b}$ with $\mathrm{Bu}_{3} \mathrm{SnH}$ which gave the tetrahydropyrrolo[3,4-b]indole 54 in excellent yield followed by oxidation with $\mathrm{MnO}_{2}$ which provided pyrrolo[3,4- $b$ ]indole 55 in modest yield (Scheme 13). 
<smiles>O=[N+]([O-])C12CN(Cc3ccccc3)CC1C1([N+](=O)c3ccccc3)c3ccccc3N21</smiles>

51b

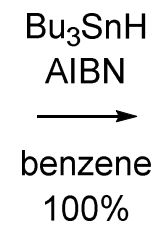

$100 \%$

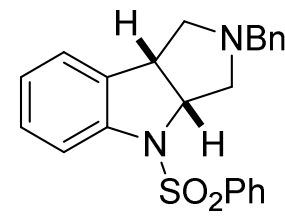

54

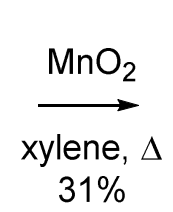

$31 \%$

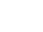<smiles></smiles>

55

\section{Scheme 13}

More recently, it has been established that a non-stabilized azomethine ylide formed under mild conditions reacts with nitro-substituted heteroaromatic derivatives. ${ }^{69,70}$ Thus, $N$ benzylazomethine ylide 49b can be formed in situ from reaction of $N$-methoxymethyl- $(N$ trimethylsilylmethyl)benzylamine $\mathbf{5 6}$ and a catalytic amount of trifluoroacetic acid at $0{ }^{\circ} \mathrm{C}$ to room temperature (Scheme 14). ${ }^{71-73}$ Consistent with the earlier work of Gribble, ${ }^{68}$ 2-nitro-1tosylindole $\mathbf{5 7}$ underwent efficient cycloaddition reaction to afford the tricyclic product $\mathbf{5 8}$ in excellent yield (Scheme 15). ${ }^{70}$ Additionally a series of 3-substituted indoles 59 underwent cycloaddition reactions with the azomethine ylide under these conditions (Scheme 16, Table 1). ${ }^{70}$ Notably, two electron-withdrawing groups are required, one on the indole nitrogen and one at indole position 3, for the cycloaddition process to occur under these conditions. Carbonyl groups are also sufficiently electron-withdrawing to facilitate the desired cycloaddition process (Table 1, entries 5-9). Low isolated yields were obtained for some examples, however, it was reported that the low yields were due to the instability of the product during isolation rather than inefficient cycloaddition reactions.<smiles>COCN(Cc1ccccc1)CC(C)C</smiles>

56

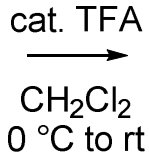

$\mathrm{O}^{\circ} \mathrm{C}$ to rt

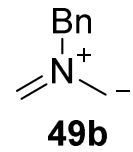

49b

\section{Scheme 14}<smiles>O=[N+]([O-])c1cc2ccccc2n1[AsH3-]</smiles>

57

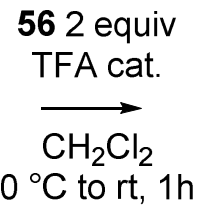

$94 \%$<smiles>[13CH3]N1c2ccccc2[C@@H]2C[C@H](Cc3ccccc3)CC21[N+](=O)[O-]</smiles>

58

\section{Scheme 15}


<smiles>[R]c1cn([R])c2ccccc12</smiles>

59

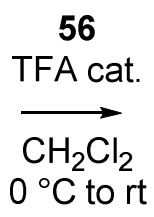

$0^{\circ} \mathrm{C}$ to rt

\section{Scheme 16}

Table 1. Reactions of 3-substituted indoles 59 with azomethine ylide 49b to afford pyrroloindoles 60

\begin{tabular}{ccccccc}
\hline Entry & $\mathbf{5 9 / 6 0}$ & $\mathrm{R}^{1}$ & $\mathrm{R}^{2}$ & Equiv. 56 & Duration $(\mathrm{h})$ & Yield 60 (\%) \\
\hline $\mathbf{1}$ & $\mathbf{a}$ & $\mathrm{NO}_{2}$ & $\mathrm{Ts}$ & 2 & 1 & 94 \\
$\mathbf{2}$ & $\mathbf{b}$ & $\mathrm{NO}_{2}$ & $\mathrm{Boc}$ & 2 & 6.5 & 85 \\
$\mathbf{3}$ & $\mathbf{c}$ & $\mathrm{NO}_{2}$ & $\mathrm{Ac}$ & 1.2 & 2 & 86 \\
$\mathbf{4}$ & $\mathbf{d}$ & $\mathrm{NO}_{2}$ & $\mathrm{Tf}$ & 1.2 & 2 & 14 \\
$\mathbf{5}$ & $\mathbf{e}$ & $\mathrm{CO}_{2} \mathrm{Me}$ & $\mathrm{Ts}$ & 1.2 & 6 & 21 \\
$\mathbf{6}$ & $\mathbf{f}$ & $\mathrm{CO}_{2} \mathrm{Me}$ & $\mathrm{Boc}$ & 1.2 & 6 & 25 \\
$\mathbf{7}$ & $\mathbf{g}$ & $\mathrm{CO}_{2} \mathrm{Me}$ & $\mathrm{Ac}$ & 1.2 & 6 & 64 \\
$\mathbf{8}$ & $\mathbf{h}$ & $\mathrm{CO}_{2} \mathrm{Me}$ & $\mathrm{Tf}$ & 1.2 & 6 & 76 \\
$\mathbf{9}$ & $\mathbf{i}$ & $\mathrm{COMe}$ & $\mathrm{Tf}$ & 1.2 & 2 & 75 \\
\hline
\end{tabular}

Whilst 3-acetylindole derivative 59i underwent exclusive dearomatizing cycloaddition, alternative cycloaddition pathways were apparent for other 3-carbonyl substituted indoles (Scheme 17). ${ }^{70}$ For $N$-triflylindole-3-carboxaldehyde 61a, three products, two mono adducts and a bis adduct, formed in a 6:2:2 ratio. The major product was isoxazolidine 62a resulting from cycloaddition to the aldehyde moiety, the other products weren't separated, but were assigned as indole $\mathrm{C} 2-\mathrm{C} 3$ cycloadduct $\mathbf{6 3 a}$ and the product from addition to both the aldehyde and C2-C3 moeities 64a. For $N$-acetyl-C3-ketocarboxylic acid ester 61b, isoxazolidine 62b was obtained in $70 \%$ yield, along with $\mathbf{6 3 b}(20 \%)$ and minor amounts of bis adduct 64b (not isolated).

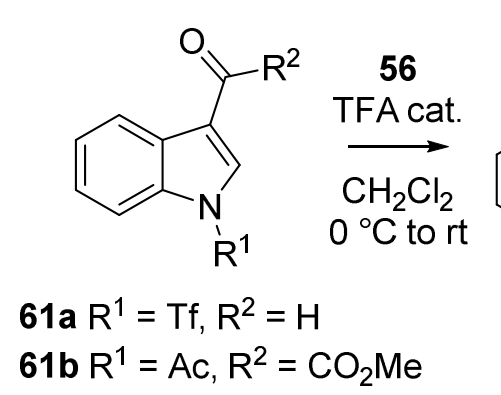<smiles>[R]n1cc(C2([R])CC[NH2+]C2)c2ccccc21</smiles>

62a $(40 \%)$

62b $(70 \%)$

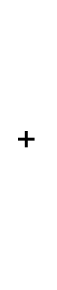<smiles>[R]C(=O)C12CN(Br)CC1([Y])c1ccccc1N2[R]</smiles>

$63 a$

63b (20\%)

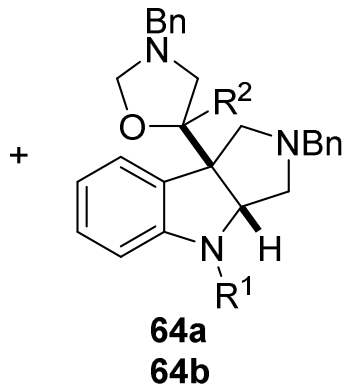

\section{Scheme 17}


Additionally, nitro-substituted benzofurans and five-membered heteroaromatic systems also readily undergo cycloaddition reactions with azomethine ylide 49b generated from precursor 56. Thus, 5-acetoxy-3-nitrobenzofuran, 3-nitro-1-tosylpyrrole, 4-nitro-1-tosylimidazole and 2nitrothiophene yield the respective cycloadducts $\mathbf{6 5}(99 \%$ yield obtained using 2 equiv. reagent 56 and a reaction time of $1 \mathrm{~h}$ ), 66 (95\% yield with 3 equiv. 56 for $21 \mathrm{~h}), \mathbf{6 7}$ (62\% yield with 2 equiv. 56 for $2 \mathrm{~h}$ ) and $\mathbf{6 8}$ (94\% with 4 equiv. $\mathbf{5 6}$ for $22 \mathrm{~h}) .{ }^{69,70}$<smiles>CC(C)Oc1ccc2c(c1)[C@@]1(N=O)CN(Cc3ccccc3)C[C@H]1O2</smiles>

$65(99 \%)$

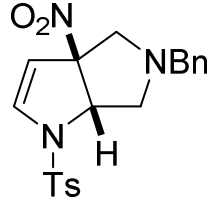

$66(95 \%)$

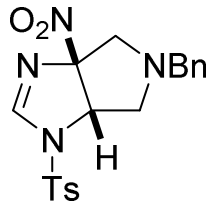

$67(62 \%)$

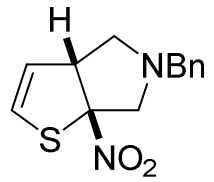

$68(94 \%)$

Cycloaddition reactions of nitropyridines were also explored. ${ }^{69,70}$ While nitropyridine and nitropyridine- $N$-oxide failed to react with azomethine ylide 49b, 3,5-dinitropyridine 69 underwent rapid reaction to give a tris cycloadduct 70, whose stereochemistry was established as syn-anti by 2D NOESY experiments (Scheme 18). ${ }^{70}$ Also, in a further interesting example, 4nitroquinoline- $N$-oxide 71 underwent regioselective two fold cycloaddition reactions to both the C3-C4 double bond and the nitrone 1,3-dipole to give exclusively the anti bis adduct 72, with the structure and stereochemistry proven by X-ray crystallographic analysis (Scheme 18). ${ }^{69,70}$

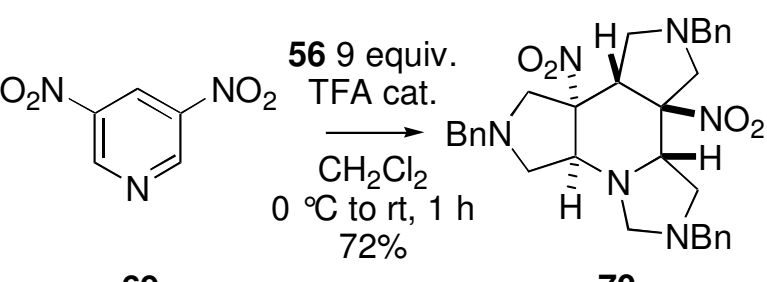

69
70<smiles>O=[N+]([O-])c1cc[n+]([O-])c2ccccc12</smiles>

71

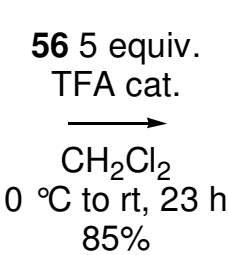

$85 \%$<smiles>O=[N+]([O-])C12CN(Cc3ccccc3)CC1C1C[NH2+]CON1c1ccccc12</smiles>

72

\section{Scheme 18}

\section{Reactions of Non-stabilized Azomethine Ylides with Nitro-substituted Benzenoid Aromatic Dipolarophiles}

Recently it was found that heterocycle-fused dinitrobenzenes $\mathbf{7 3}$ readily undergo 1,3-dipolar cycloaddition reactions with azomethine ylide $49 \mathbf{a}$, formed by decarboxylative condensation of sarcosine 47a and paraformaldehyde (Scheme 10), to form novel tetracyclic ring systems 74 (Scheme 19). ${ }^{74-76}$ Dinitro-indazole 73a, -benzoisoxazole 73b, -benzothiadiazole 73c, -benzotriazole 73d, -quinoline 73e and -benzoisothiazole $\mathbf{7 3 f}$ all undergo twofold cycloaddition reactions to afford the respective tetracyclic heterosystems $\mathbf{7 4 a - f}$, in low to moderate yields. The reactions are reported to be diastereoselective with only a single isomer isolated and the crystal structures of representative examples showing that the products are the anti bis adducts, i.e., 
resulting from cycloaddition of two ylide equivalents to the opposing faces of the dinitrobenzo ring system.<smiles>CNCC(=O)OCc1ccccc1</smiles>

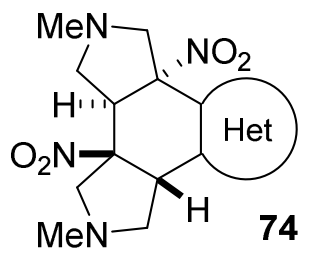

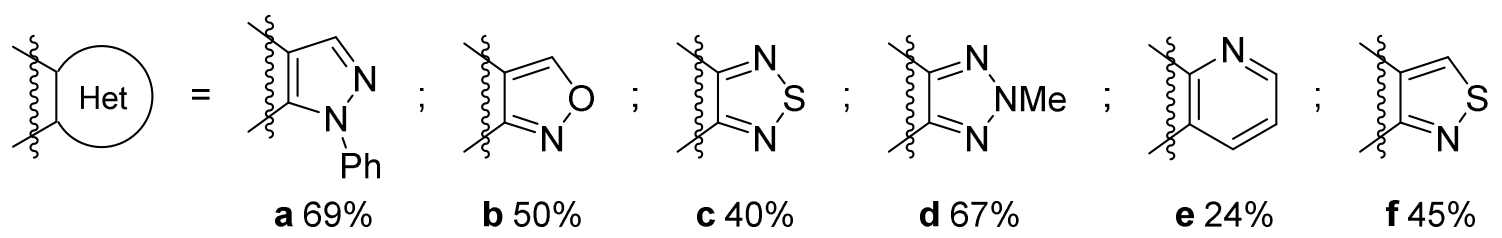

\section{Scheme 19}

Furthermore, the twofold cycloaddition reaction was possible even in the presence of one nitro group, as illustrated by the reaction of the nitrotriazolo[1,5-a]pyrimidine $\mathbf{7 5}$ which afforded tetracycle 76, although in this case the stereochemistry was not established (Scheme 20). Interestingly, this is also an example of reaction of the azomethine ylide with a heteroaromatic $\mathrm{C}=\mathrm{N}$ bond.<smiles>O=[N+]([O-])c1cnc2ncnn2c1</smiles>

75
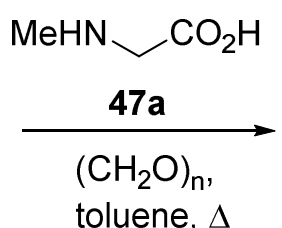

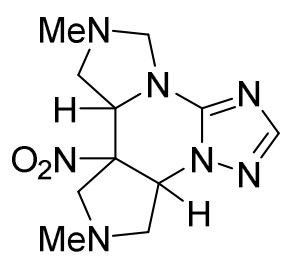

$7642 \%$

\section{Scheme 20}

Certain heterocycle-fused nitrobenzenes undergo selective mono additions of azomethine ylide 49a, formed in situ from sarcosine 47a and paraformaldehyde (Scheme 10). ${ }^{77}$ Thus, benzofused heterocycles $\mathbf{7 7}$ react to formed the tricyclic products $\mathbf{7 8}$ without sign of second addition of the azomethine ylide or rearomatization (Scheme 21, Table 2). With introduction of an electronwithdrawing group such as a sulfone at position 4 in $\mathbf{7 9}$, cycloaddition does occur, however, across the nitro-substituted C6-C7 double bond. In this case, the rearomatised products 81 were isolated, presumably by loss of nitrous acid from the initial cycloadducts $\mathbf{8 0}$ (Scheme 22, Table 3). It was shown that 6-nitroindazoles substituted with hydrogen or electron-releasing substituents (e.g., $\mathrm{OPh}, \mathrm{SPh}, \mathrm{OMe}$ ) at the 4-position do not undergo such cycloaddition reactions, 
except for a special case where the electron-releasing group is part of a peri annelated ring system 82 (Scheme 23).<smiles>[Y][Y]1ccc([R])c2ccc([R])c12</smiles>

77

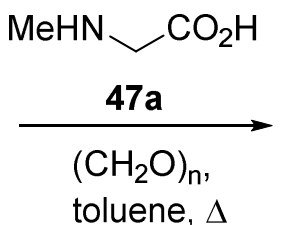

toluene, $\Delta$<smiles>[Y][X]c1ccc2c(c1)C1([R])CNCC1([R7])CN2</smiles>

78

\section{Scheme 21}

Table 2. Reactions of bicyclic heteroaromatics 77 with azomethine ylide 49a

\begin{tabular}{cccccc}
\hline Entry & $\mathrm{R}^{1}$ & $\mathrm{R}^{2}$ & $\mathrm{X}$ & $\mathrm{Y}$ & Isolated Yield 78 (\%) \\
\hline 1 & $\mathrm{H}$ & $\mathrm{NO}_{2}$ & $\mathrm{O}$ & $\mathrm{N}$ & 75 \\
2 & $\mathrm{H}$ & $\mathrm{NO}_{2}$ & $\mathrm{~S}$ & $\mathrm{~N}$ & 42 \\
3 & $\mathrm{NO}_{2}$ & $\mathrm{H}$ & $\mathrm{O}$ & $\mathrm{CH}$ & 40 \\
4 & $\mathrm{NO}_{2}$ & $\mathrm{H}$ & $\mathrm{O}$ & $\mathrm{N}$ & 98 \\
5 & $\mathrm{NO}_{2}$ & $\mathrm{H}$ & $\mathrm{S}$ & $\mathrm{N}$ & 64 \\
\hline
\end{tabular}<smiles>[R2]c1n[X]c2cc([N+](=O)[O-])cc(S(=O)(=O)OCCCC(=O)O)c12</smiles>

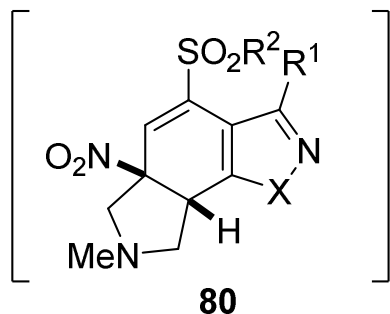<smiles>[R1]c1n[X]c2c(S(=O)(=O)O)cc3c(c2c1[R])CN(C)C3</smiles>

\section{Scheme 22}

Table 3. Reactions of sulfonyl-substituted heterocycle-fused nitrobenzenes $\mathbf{7 9}$ with azomethine ylide 49a.

\begin{tabular}{ccccc}
\hline Entry & $\mathrm{X}$ & $\mathrm{R}^{1}$ & $\mathrm{R}^{2}$ & Isolated yield 81 (\%) \\
\hline 1 & $\mathrm{NPh}$ & $\mathrm{H}$ & $\mathrm{Ph}$ & 30 \\
2 & $\mathrm{NPh}$ & $\mathrm{H}$ & $\mathrm{Bn}$ & 32 \\
3 & $\mathrm{NPh}$ & $\mathrm{CO}_{2} \mathrm{Et}$ & $\mathrm{Bn}$ & 54 \\
4 & $\mathrm{NPh}$ & $\mathrm{CONHC}_{6} \mathrm{H}_{4}-4-\mathrm{OMe}$ & $\mathrm{Bn}$ & 61 \\
5 & $\mathrm{O}$ & 1,3 -dioxan-2-yl & $\mathrm{Bn}$ & 30 \\
6 & $\mathrm{O}$ & 1,3 -dioxan-2-yl & $\mathrm{Ph}$ & 39 \\
7 & $\mathrm{O}$ & 1,3 -dioxan-2-yl & $\mathrm{c}^{-} \mathrm{C}_{6} \mathrm{H}_{11}$ & 64 \\
8 & $\mathrm{O}$ & 1,3 -dioxan-2-yl & $\left(\mathrm{CH}_{2}\right)_{2} \mathrm{CO}_{2} \mathrm{Me}$ & 40 \\
\hline
\end{tabular}




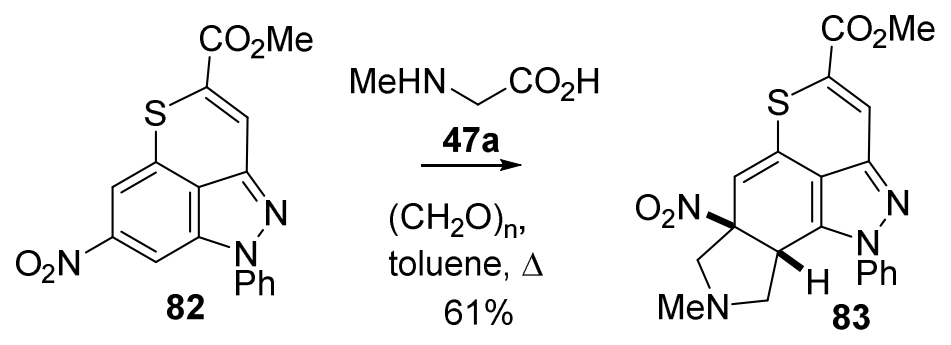

\section{Scheme 23}

The ability of azomethine ylide 49b, formed from reagent 56 (Scheme 14), to undergo cycloaddition reactions with isolated nitrobenzene systems was more recently revealed. ${ }^{69,70}$ While nitrobenzene itself does not react to an observable extent with the ylide 49b, even with a large excess of the reagent 56, dinitrobenzenes such as 1,3-dinitrobenzene 84 and 1,4dinitrobenzene $\mathbf{8 6}$ give bis adducts 85 and 87 in $85 \%$ and $69 \%$ yield, respectively (Scheme 24). No evidence for mono adducts were observed in these reactions, indicating that the mono adduct must be much more reactive towards azomethine ylide $49 \mathrm{~b}$ than the starting material. NOESY experiments were used to determine the stereochemistry of bis adduct $\mathbf{8 5}$, namely that the pyrrolidine rings are both cis fused to the central cyclohexene ring and are in an anti relationship relative to one another. The stereochemistry of $\mathbf{8 7}$ was also assigned as anti. In the case of 1,2dinitrobenzene 88, a bis adduct was also obtained, albeit in modest yield, however, the stereochemistry was shown by X-ray crystallographic analysis to be the cis-syn-cis adduct 89 (Scheme 25). The different reaction rate and stereochemical outcome for 1,2-dinitrobenzene was attributed to a combination of stereoelectronic effects in the starting material and presumed intermediate mono adduct. ${ }^{70}$
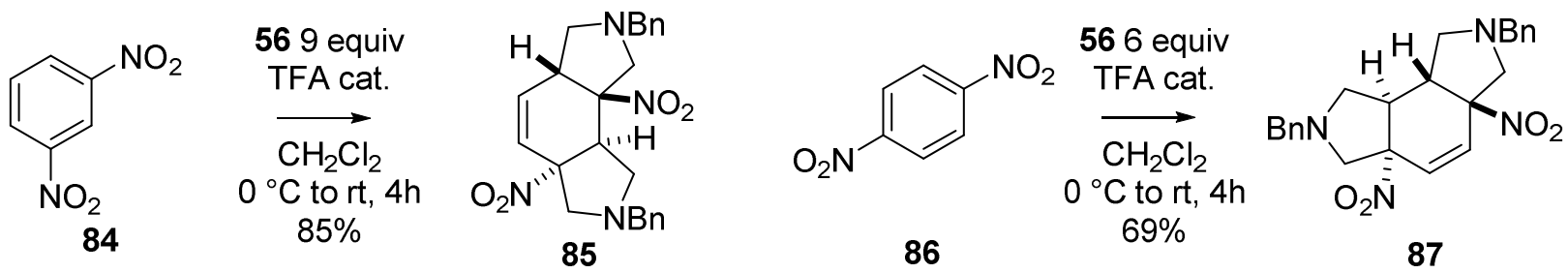

\section{Scheme 24}
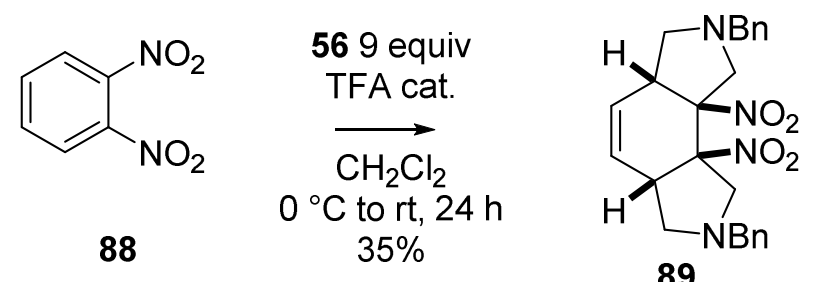

Scheme 25 
The bis cycloaddition reaction works in a similar manner for nitrobenzenes substituted with electron-withdrawing groups, with a range of regioselectivities being observed depending on the nature of the electron withdrawing group. ${ }^{69,70}$ Whilst theoretically there are four potential anti bis adducts that could arise from 3-chloronitrobenzene 90 and 3,4-dichloronitrobenzene 91, only single regiosiomeric bis adducts, 92 and 93 were obtained, respectively (Scheme 26). In contrast, the reactions of the corresponding 3-trifluoromethyl-1-nitrobenzene derivatives 94 to 97 delivered a range of products depending on the analogue (Scheme 27). Thus, reaction of 3trifluoromethyl-1-nitrobenzene 94 with ylide 49b formed from nine equivalents of reagent 56 over a $24 \mathrm{~h}$ period led to a mixture of all four possible anti regioisomers $\mathbf{9 8 a - d}$, produced in good yield, although only the major regioisomer 98c was isolated in pure form. For the substrate 2chloro-5-trifluoromethylinitrobenzene 95, only one regioisomer 99a was isolated, a result which was thought to be due to the relative unreactivity of the vinyl chloride moiety towards the azomethine ylide. The related 2-fluoro analogue 96 afforded a ca. 1:1 mixture of two regioisomers $\mathbf{1 0 0 a}$ and $\mathbf{1 0 0 b}$, indicating similar reactivity of the vinyl fluoride and the vinyl trifluoromethide moieties within the presumed mono adduct. As might now be expected, the symmetrical starting material 3,5-bis(trifluoromethyl)nitrobenzene 97 delivered a mixture of the two possible anti regioisomers 101a and 101b.

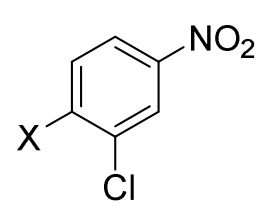

$90 X=\mathrm{H}$

$91 \mathrm{X}=\mathrm{Cl}$

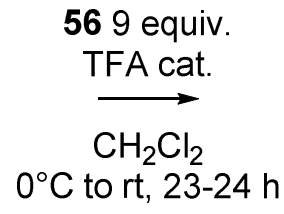

$\mathrm{O}^{\circ} \mathrm{C}$ to rt, $23-24 \mathrm{~h}$

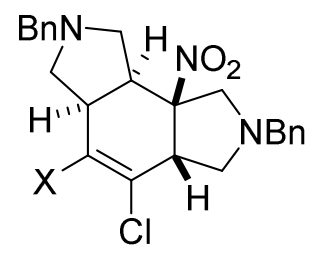

$92 \mathrm{X}=\mathrm{H}(33 \%)$

$93 \mathrm{X}=\mathrm{Cl}(81 \%)$

\section{Scheme 26}

In the case of nitrobenzenes, substituted with mesomeric electron-withdrawing groups, again mixtures of anti bis adducts were obtained (Scheme 28). ${ }^{69,70}$ In the case of methyl 3-nitrobenzoate 102, a ca. 1:1 ratio of two regioisomeric anti bis cycloadducts 105 a and 105c were obtained in a combined yield of $62 \%$. The regio- and stereochemistry of $\mathbf{1 0 5 a}$ and $\mathbf{1 0 5} \mathbf{c}$ were determined using a range of 2D NMR experiments. Similar results were obtained for the 3cyano-1-nitrobenzene 103, whereby bis adducts $106 \mathbf{a}$ and $106 \mathbf{c}$ were isolated. Further incorporation of a chloro substituent para to the nitro group, as in 104, also led to two regioisomeric bis adducts, however, it was shown that different regiosiomers $107 \mathbf{b}$ and $\mathbf{1 0 7 c}$ were produced in this case. The lack of reactivity of the vinyl chloride moiety is again apparent, apparently influencing the direction of the second addition of azomethine ylide. 
<smiles>[R]c1cc(C(F)(F)F)cc([N+](=O)[O-])c1[R]</smiles>

$$
\begin{aligned}
& 94 \mathrm{R}^{1}=\mathrm{R}^{2}=\mathrm{H} \\
& 95 \mathrm{R}^{1}=\mathrm{H}, \mathrm{R}^{2}=\mathrm{Cl} \\
& 96 \mathrm{R}^{1}=\mathrm{H}, \mathrm{R}^{2}=\mathrm{F} \\
& 97 \mathrm{R}^{1}=\mathrm{CF}_{3}, \mathrm{R}^{2}=\mathrm{H}
\end{aligned}
$$

$\downarrow \begin{aligned} & 56 \\ & \text { cat. TFA }\end{aligned}$

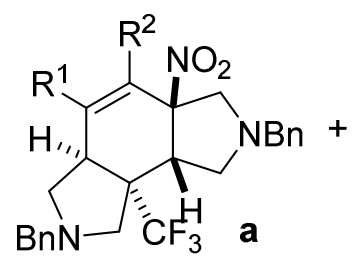

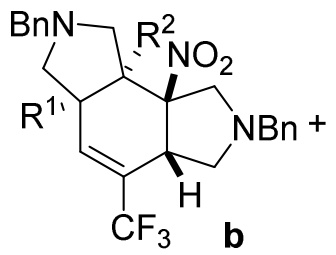<smiles>[R]C1=C[C@]2([R])CN(CC(F)(F)F)C[C@]2([N+](=O)[O-])C[C@H]1CBr</smiles>

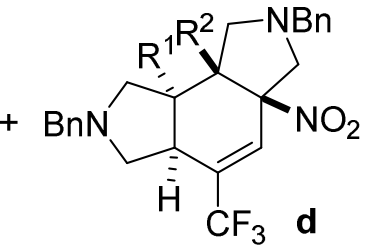

$98(79 \%$, a:b:c:d = 10:15:55:20)

$99(77 \%, \mathbf{a}: \mathbf{b}: \mathbf{c}: \mathbf{d}=100: 0: 0: 0)$

$100(78 \%, \mathbf{a}: \mathbf{b}: \mathbf{c}: \mathbf{d}=58: 42: 0: 0)$

$101(98 \%, \mathbf{a}: \mathbf{b}=30: 70)$

\section{Scheme 27}<smiles>[R]c1ccc([N+](=O)[O-])cc1[R]</smiles>

$$
\begin{aligned}
102 \mathrm{R}^{1} & =\mathrm{CO}_{2} \mathrm{Me}, \mathrm{R}^{2}=\mathrm{H} \\
103 \mathrm{R}^{1} & =\mathrm{CN}, \mathrm{R}^{2}=\mathrm{H} \\
104 \mathrm{R}^{1} & =\mathrm{CN}, \mathrm{R}^{2}=\mathrm{Cl}
\end{aligned}
$$

$$
\begin{gathered}
56 \text { 6-9 equiv } \\
\text { TFA cat. } \\
\mathrm{CH}_{2} \mathrm{Cl}_{2} \\
0{ }^{\circ} \mathrm{C} \text { to rt, } 2-24 \mathrm{~h}
\end{gathered}
$$

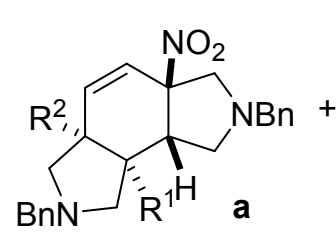

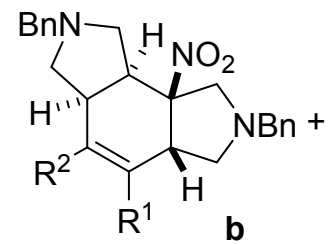

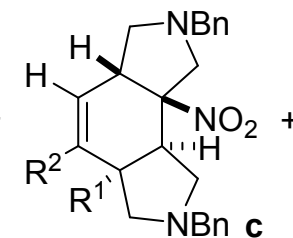<smiles></smiles>

$105(62 \%$, a:b:c:d $=53: 0: 47: 0)$

$106(61 \%$, a:b:c: $\mathbf{d}=63: 0: 37: 0)$

$107(76 \%$, a:b:c:d $=0: 53: 47: 0)$

\section{Scheme 28}

Nitronaphthalenes were shown to react efficiently with ylide $49 \mathrm{~b}$ under these conditions. ${ }^{69,70}$ 1-Nitronaphthalene 108 reacted regioselectively with ylide $49 \mathrm{~b}$ to afford a mono adduct $\mathbf{1 0 9}$, demonstrating the greater reactivity of 1-nitronaphthalene over nitrobenzene (Scheme 29). 1,5- 
Dinitronaphthalene 110, with an additional nitro group, led to faster reactions with the ylide $\mathbf{4 9 b}$. When just two equivalents of the ylide precursor 56 were used, the mono adduct 111 was obtained together with traces amount of bis adduct 112. On the other hand, when 6 equivalents of the ylide precursor 56 were used together with longer reaction times, the bis adduct 112 was obtained as the major product (Scheme 30).<smiles>O=[N+]([O-])c1cccc2ccccc12</smiles>

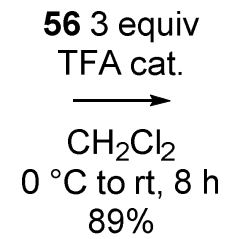<smiles>O=[N+]([O-])C12C=Cc3ccccc3C1CN(Cc1ccccc1)C2</smiles>

\section{Scheme 29}

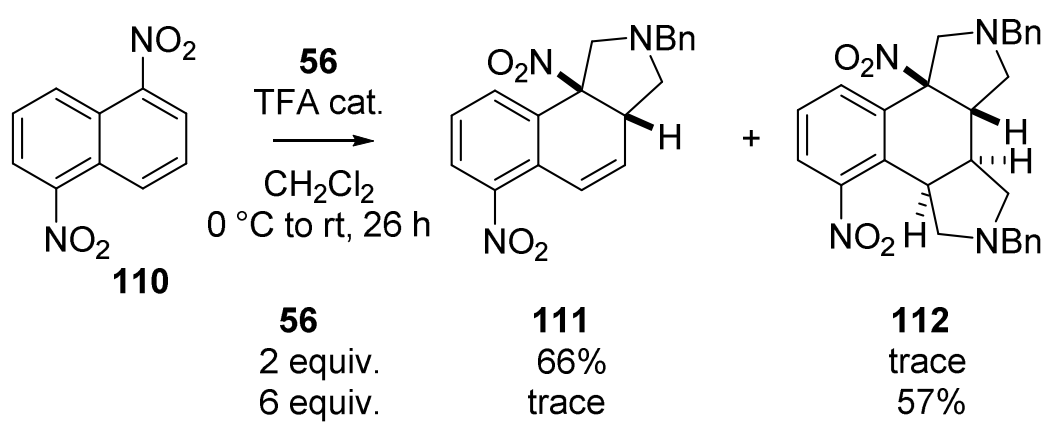

\section{Scheme 30}

Interestingly, heterocycle-fused nitrobenzenes, 6-nitroindazole $\mathbf{1 1 3}$ and 5-nitroquinoline 115, underwent selective cycloaddition reactions on the nitrated aromatic ring system to afford single mono adducts 114 (64\%) and 116 (80\%), respectively (Scheme 31). ${ }^{69,70}$ Although not directly comparable, these results are consistent with the observations of cycloaddition on pyrazole-fused dinitrobenzene derivative 73a and pyridine-fused dinitrobenzene 73e, discussed earlier (Scheme 19). ${ }^{74-76}$ Similarly, 6- and 8-nitroquinoline, 6-nitroisoquinoline and 5-nitro-1,10-phenanthroline all undergo selective single cycloaddition on the nitro-substituted ring to give the respective mono cycloadducts 117, 118, 119 and 120.

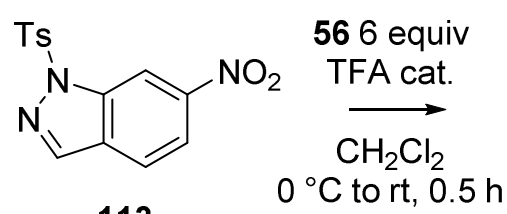

113 $64 \%$<smiles>Cn1ncc2c1C1(Cc3ccccc3)CNC1([N+](=O)[O-])C=C2</smiles>

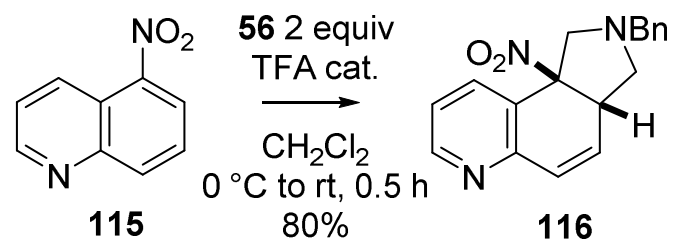

\section{Scheme 31}


<smiles></smiles>

117<smiles>O=[N+]([O-])C1([N+](=O)[O-])CCN(Cc2ccccc2)C1</smiles>

118<smiles>O=[N+]1CC[C@@H]2C[C@@H]1C=Cc1cnccc12</smiles>

119<smiles>O=[N+]([O-])C12C[C@H](Cc3ccccc3)C[C@@H]3c4cccnc4-c4ncccc4[C@H]1C32</smiles>

120

Finally and promisingly, it was shown that groups other than the nitro group can facilitate cycloaddition of azomethine ylide $49 \mathrm{~b}$ to benzenoid aromatic systems. Thus, the tetramethyl ester of benzene-tetracarboxylic acid $\mathbf{1 2 1}$ underwent cycloaddition reactions to afford a ca. 1:2 mixture of bis adducts 122 and 123 (Scheme 32).$^{70}$ [Note: Ref. 70, Table 3 Entry 5 indicates that the product depicted here as structure $\mathbf{1 2 2}$ is the minor product from the reaction, whereas the text indicates that it is the major product] Although the stereochemistry of bis adduct $\mathbf{1 2 3}$ was determined to be anti by 2D NMR experiments, the stereochemistry of symmetrical bis adduct 122 was not determined.

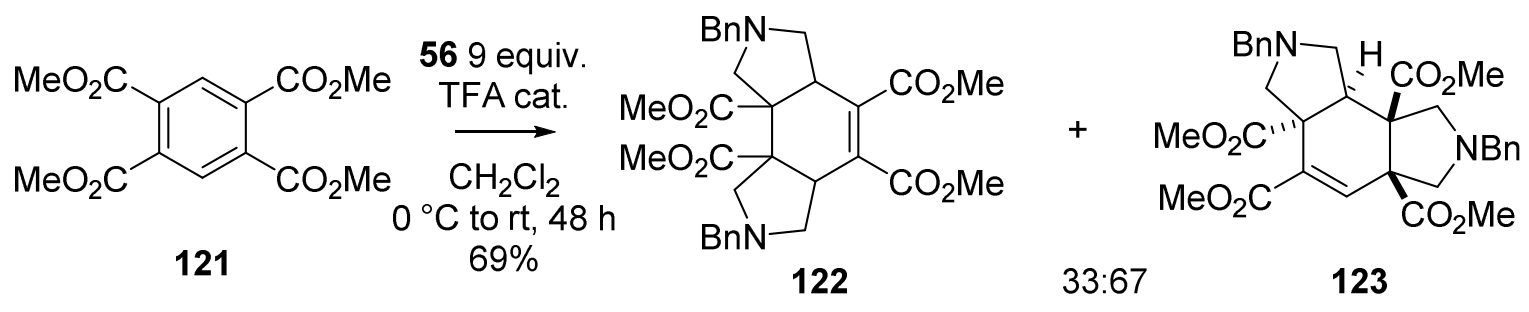

\section{Scheme 32}

\section{Mechanism}

The mechanism of the cycloadditions was considered theoretically. ${ }^{70}$ DFT calculations on model compounds indicate that a concerted mechanism features a low activation barrier compared with an alternative cycloaddition process involving a nitrobenzene radical anion and an azomethine ylide radical cation.

\section{Acknowledgements}

This work was supported by CSIRO's Manufacturing Flagship. I acknowledge the invitation and encouragement of Dr Viktor Zhdankin to write this review.

\section{References}

1. Kuhl, N.; Hopkinson, M. N.; Wencel-Delord, J.; Glorius, F. Angew. Chem. Int. Ed. 2012, 51, 10236 (recent review). 
http://dx.doi.org/10.1002/anie.201203269

2. Zhao, D.; Lied, F.; Glorius, F. Chem. Sci. 2014, 5, 2869. http://dx/doi.org/10.1039/c4sc00628c

3. Zhai, C.; Xing, D.; Jing, C.; Zhou, J.; Wang, C.; Wang, D.; Hu, W. Org. Lett. 2014, 16, 2934. http://dx/doi.org/10.1021/ol5010752

4. Yu, Z.; Ma, B.; Chen, M.; Wu, H.-W.; Liu, L.; Zhang, J. J. Am. Chem. Soc. 2014, 136, 6904. http://dx/doi.org/10.1021/ja503163k

5. Morofuji, T.; Shimizu, A.; Yoshida, J. J. Am. Chem. Soc. 2014, 136, 4496. http://dx/doi.org/10.1021/ja501093m

6. Roche, S. P.; Porco, J. A. Angew. Chem. Int. Ed. 2011, 50, 4068 (recent review). http://dx/doi.org/10.1002/anie.201006017

7. Zhuo, C.-X.; Zhang, W.; You, S.-L. Angew. Chem. Int. Ed. 2012, 51, 12662 (recent review). http://dx/doi.org/10.1002/anie.201204822

8. Schultz, A. G. Chem. Comm. 1999, 1263 (review). http://dx/doi.org/10.1039/A901759C

9. Rabideau, P. W.; Marcinow, Z. In Organic Reactions; Wiley: New York, 1992; Vol. 42, Ch.1, 1.

10. Nawrat, C. C.; Kitson, R. R. A.; Moody, C. J. Org. Lett. 2014, 16, 1896. http://dx/doi.org/10.1021/ol5003847

11. Taber, D. F.; Paquette, C. M. J. Org. Chem. 2014, 79, 3410. http://dx/doi.org/10.1021/jo500164x

12. Lewis, S. E. Chem. Commun. 2014, 50, 2821 (recent review). http://dx/doi.org/10.1039/c3cc49694e

13. Boyd, D. R.; Sharma, N. D.; Carroll, J. G.; Loke, P. L.; O’Dowd, C. R.; Allen, C. C. R. RSC Advances 2013, 3, 10944. http://dx/doi.org/10.1039/c3ra42026d

14. Bon, D. J.-Y. D.; Banwell, M. G.; Willis, A. C. Tetrahedron 2010, 66, 7807. http://dx/doi.org/10.1016/j.tet.2010.07.059

15. Ding, Q.; Ye, Y.; Fan, R. Synthesis, 2013, 45, 1 (recent review). http://dx/doi.org/10.1055/s-0032-1317575

16. Jackson, S. K.; Wu, K.-L.; Pettus, T. R. R. In Biomimetic Organic Syntheses; Poupon, E.; Nay, B. Eds.; Wiley-VCH: Weinheim, 2011; Vol. 2, Ch. 20, 723. http://dx/doi.org/10.1002/9783527634606.ch20

17. Pouységu, L.; Deffieux, D.; Quideau, S. Tetrahedron 2010, 66, 2235 (recent review). http://dx/doi.org/10.1016/j.tet.2009.12.046

18. Singh, V. Synlett 2013, 24, 2641 (recent review). http://dx/doi.org/10. 1055/s-0033-1338978

19. Kuwaja, S.; Best, D.; Burns, D. J.; Lam, H. W. Chem. Eur. J. 2014, $20,1$. http://dx/doi.org/10.1002/chem.201403454

20. Hin, Z.; Zhang, L.; Li, Z.; Fan, R. Angew. Chem. Int. Ed. 2014, 53, 6805. 
http://dx/doi.org/10.1002/anie.201404155

21. Wei, L.; Xiao, M.; Xie, Z. Org. Lett. 2014, 16, 2784. http://dx/doi.org/10.1021/ol501050s

22. Boll, M. J. Mol. Microbiol. Biotechnol. 2005, 10, 132 (review). http://dx/doi.org/10.1159/000091560

23. Harrison, D. P.; Harman, W. D. Aldrichimica Acta 2012, 45, 45.

24. Rosillo, M.; Dominguez, G.; Pérez-Castells, J. Chem. Soc. Rev. 2007, 36, 1589. http://dx/doi.org/10.1039/B606665H

25. Pape, A. R.; Kaliappan, K. P.; Kündig, E. P. Chem. Rev. 2000, 100, 2917. http://dx/doi.org/10.1021/cr9902852

26. Lemiere, G.; Clayden, J. Science of Synthesis, Knowledge Updates 2011, 4, 139.

27. Ortiz, F. L.; Iglesias, M. J.; Fernández, I.; Sánchez, C. M. A.; Gómez, G. R. Chem. Rev. 2007, 107, 1580.

http://dx/doi.org/10.1021/cr0302071

28. Clayden, J In Strategies and Tactics in Organic Synthesis; Harmata, M. Ed.; Elsevier, 2004; Vol. 4, Ch. 4, 71. http://dx/doi/org/10.1016/S1874-6004(04)80008-X

29. Ishida, T.; Ikota, H.; Kurahashi, K.; Tsukano, C.; Takemoto, Y. Angew. Chem. Int. Ed. 2013, $52,10204$. http://dx/doi.org/10.1002/anie.201305581

30. Senczyszyn, J.; Brice, H.; Clayden, J. Org. Lett. 2013, 15, 1922. http://dx/doi.org/10.1021/ol400571j

31. Peng, Bo.; Zhang, S.; Yu, X.; Feng, X.; Bao, M. Org. Lett. 2011, 13, 5402. http://dx/doi.org/10.1021/ol2023278

32. Qi, S.-C.; Wei, X.-Y.; Zong, Z.-M.; Wang, Y.-K. RSC Advances 2013, 3, 14219 (recent review). http://dx/doi.org/10.1039/c3ra40848e

33. Wang, D.-S.; Chen, Q.-A.; Lu, S.-M.; Zhou, Y.-G. Chem. Rev. 2012, 112, 2557. http://dx/doi.org/10.1021/cr200328h

34. Sánchez, A.; Fang, M.; Ahmed, A.; Sánchez-Delgado, R. A. Appl. Catal. A: Gen. 2014, 477, 117. http://dx/doi.org/10.1016/j.apcata.2014.03.009

35. Duan, H.; Wang, D.; Kou, Y.; Li, Y. Chem. Commun. 2013, 49, 303. http://dx/doi.org/10.1039/c2cc37668g

36. Stork, G.; Yamashita, A.; Adams, J.; Schulte, G. R.; Chesworth, R.; Miyazaki, Y.; Farmer, J. J. J. Am. Chem. Soc. 2009, 131, 11402. http://dx/doi.org/10.1021/ja9038505

37. Martin, D. B. C.; Vanderwal, C. D. J. Am. Chem. Soc. 2009, 131, 3472. http://dx/doi.org/10.1021/ja900640v

38. Campbell, E. L.; Zuhl, A. M.; Liu, C. M.; Boger, D. L. J. Am. Chem. Soc. 2010, 132, 3009. 
http://dx/doi.org/10.1021/ja908819q

39. Shimada, N.; Oohara, T.; Krishnamurthi, J.; Nambu, H.; Hashimoto, S. Org. Lett. 2011, 13, 6284. http://dx/doi.org/10.1021/ol2027625

40. Trost, B. M.; Ehmke, V.; O’ Keefe, M.; Bringley, D. A. J. Am. Chem. Soc. 2014, 136, 8213. http://dx/doi.org/10.1021/ja5044825

41. Pandey, G.; Banerjee, P.; Gadre, S. R. Chem. Rev. 2006, 106, 4484.

http://dx/doi.org/10.1021/cr050011g

42. Huisgen, R.; Niklas, K. Heterocycles 1984, 22, 21. http://dx/doi/org/10.3987/R-1984-01-0021

43. Song, G.; Chen, D.; Su, Y.; Han, K.; Pan, C.-L.; Jia, A.; Li, X. Angew. Chem. Int. Ed. 2011, $50,7791$. http://dx/doi.org/10.1002/anie.201102561

44. Lee, D. J.; Han, H. S.; Shin, J.; Yoo, E. J. J. Am. Chem. Soc. 2014, 136, 11606. http://dx/doi.org/10.1021/ja5061609

45. Speck, K.; Magauer, T. Beilstein J. Org. Chem. 2013, 9, 2048. http://dx/doi.org/10.3762/bjoc.9.243

46. Phillippe, H. M.; Wargo, K. A. Exp. Opin. Pharmacother. 2013, 14, 2133. http://dx/doi.org/10.1517/14656566.2013.834048

47. Galustian, C.; Dalgleish, A. Exp. Opin. Pharmacother. 2009, 10, 125. http://dx/doi.org/10.1517/14656560802627903

48. Maggini, M.; Scorrano, G.; Prato, M. J. Am. Chem. Soc. 1993, 115, 9798. http://dx/doi.org/10.1021/ja00074a056

49. Prato, M.; Maggini, M. Acc. Chem. Res. 1998, 31, 519. http://dx/doi.org/10.1021/ar970210p

50. Ruiz, A.; Morera-Boado, C.; Almagro, L.; Coro, J.; Maroto, E. E.; Herranz, M. A.; Filippone, S.; Molero, D.; Martinez-Alvarez, R.; Garcia de la Vega, J. M.; Suárez, M.; Martín, N. J. Org. Chem. 2014, 79, 3473. http://dx/doi.org/10.1021/jo500178t

51. Aroua, S.; Schweizer, W. B.; Yamakoshi, Y. Org. Lett. 2014, 16, 1688. http://dx/doi.org/10.1021/o1500363r

52. Maroto, E. E.; Filippone, S.; Suarez, M.; Martinez-Alvarez, R.; de Cozar, A.; Cossio, F. P.; Martin, N. J. Am. Chem. Soc. 2014, 136, 705. http://dx/doi.org/10.1021/ja410408c

53. Huisgen, R.; Scheer, W. Tetrahedron Lett. 1971, 12, 481. http://dx/doi.org/10.1016/S0040-4039(01)96474-3

54. Henke, B. R.; Kouklis, A. J.; Heathcock, C. H. J. Org. Chem. 1992, 57, 7056. http://dx/doi.org/10.1021/jo00052a015

55. Tsuge, O.; Ueno, K.; Kanemasa, S. Chem. Lett. 1984, 285. http://dx/doi.org/10.1246/cl.1984.285 
56. Tsuge, O.; Ueno, K.; Kanemasa, S. Chem. Lett. 1984, 797. http://dx/doi.org/10.1246/cl.1984.797

57. Grigg, R.; Gunaratne, H. Q. N. Tetrahedron Lett. 1983, 24, 1201. http://dx/doi.org/10.1016/S0040-4039(00)86404-7

58. Tsuge, O.; Ueno, K.; Oe, K. Chem. Lett. 1979, 8, 1407. http://dx/doi.org/10.1246/cl.1979.1407

59. Grigg, R.; Jordan, M.; Malone, F. Tetrahedron Lett. 1979, 20, 3877. http://dx/doi.org/10.1016/S0040-4039(01)95550-9

60. Tsuge, O.; Ueno, K.; Ueda, I. Heterocycles 1981, 16, 1503. http://dx/doi.org/10.3987/R-1981-09-1503

61. Freeman, J. P. Chem. Rev. 1983, 83, 241. http://dx/doi.org/10.1021/cr00055a002

62. Heine, H. W.; Peavy, R. Durbetaki, A. J. J. Org. Chem. 1966, 31, 3924. http://dx/doi.org/10.1021/jo01350a010

63. Huisgen, R.; Scheer, W.; Mäder, H. Angew. Chem. 1969, 81, 619. http://dx/doi.org/10.1002/ange.19690811605

64. Padwa, A.; Glazer, E. J. Org. Chem. 1973, 38, 284. http://dx/doi.org/10.1021/jo00942a018

65. Rizzi, G. P. J. Org. Chem. 1970, 35, 2069. http://dx/doi.org/10.1021/jo00831a098

66. Joucla, M.; Mortier, J. J. Chem. Soc., Chem. Commun. 1985, 1566. http://dx/doi.org/10.1039/C39850001566

67. Tsuge, O.; Kanemasa, S.; Ohe, M.; Takenaka, S. Chem. Lett. 1986, 973. http://dx/doi.org/10.1246/cl.1986.973

68. Roy, S.; Kishbaugh, T. L. S.; Jasinski, J. P.; Gribble, G. W. Tetrahedron Lett. 2007, 48, 1313. http://dx/doi.org/10.1016/j.tetlet.2006.12.125

69. Lee, S.; Chataigner, I.; Piettre, S. R. Angew. Chem. Int. Ed. 2011, 50, 472. http://dx/doi.org/10.1002/anie.201005779

70. Lee, S.; Diab, S.; Queval, P.; Sebban, M.; Chataigner, I.; Piettre, S. R. Chem. Eur. J. 2013, $19,7181$.

http://dx/doi.org/10.1002/chem.201201238

71. Padwa, A.; Dent, W. J. Org. Chem. 1987, 52, 235. http://dx/doi.org/10.1021/jo00378a013

72. Hosomi, A.; Sakata, Y.; Sakurai, H. Chem. Lett. 1984, 1117. http://dx/doi.org/10.1246/cl.1984.1117

73. Terao, Y.; Kotaki, H.; Imai, N.; Achiwa, K. Chem. Pharm. Bull. 1985, 33, 2762. http://dx/doi.org/10.1248/cpb.33.2762

74. Bastrakov, M. A.; Starosotnikov, A. M.; Pechenkin, S. Y.; Kachala, V. V.; Glukhov, I. V.; Shevelev, S. A. J. Heterocyclic Chem. 2010, 47, 893. 


\section{http://dx/doi.org/10.1002/jhet.423}

75. Starosotnikov, A. M.; Leontieva, M. A.; Bastrakov, M. A.; Puchnin, A. V.; Kachala, V. V.; Shevelev, S. A Mendeleev Commun. 2010, 20, 165. http://dx/doi.org/10.1016/j.mencom.2010.05.014

76. Konstantinova, L. S.; Bastrakov, M. A.; Starosotnikov, A. M.; Glukhov, I. V.; Lysov, K. A.; Rakitin, O. A.; Shevelev, S. A Mendeleev Commun. 2010, 20, 353. http://dx/doi.org/10.1016/j.mencom.2010.11.018

77. Starosotnikov, A. M.; Bastrakov, M. A.; Pechenkin, S. Y.; Leontieva, M. A.; Kachala, V. V.; Shevelev, S. A. J. Heterocyclic Chem. 2011, 48, 824. http://dx/doi.org/10.1002/jhet.599

\section{Author's Biography}

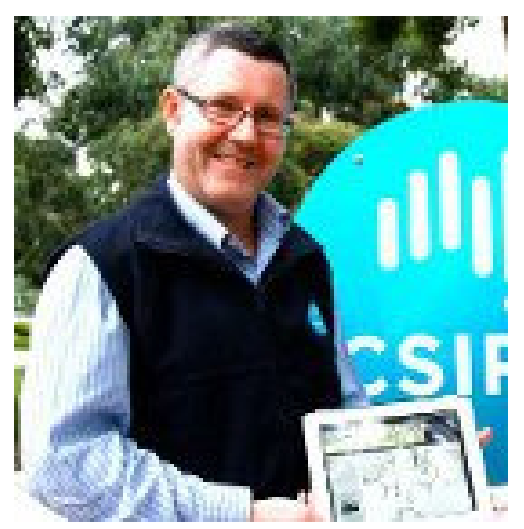

John H. (Jack) Ryan studied chemistry at The University of Melbourne, gaining a BSc Hons (1st Class) in 1989 and a PhD on cyclopropane chemistry in 1994, supervised by Martin Banwell. He undertook postdoctoral appointments researching iodonium chemistry with Peter Stang (University of Utah), and supramolecular chemistry with George Meehan and Len Lindoy (James Cook University). He gained academic experience lecturing at the University of Tasmania and industry experience as a process research and development chemist at the Institute of Drug Technology Australia. He was appointed to CSIRO as a Research Scientist in 2001 and was promoted to Senior Principal Research Scientist level in 2013. His research interests involve a combination of fundamental (reactive intermediates, reaction mechanisms, heterocyclic chemistry) and applied chemistry (medicinal chemistry, peptide mimetics, fragment-based drug discovery, chemical process development and scale-up and flow chemistry) spanning the fields of human health, natural insecticides, photoprotection and chemical manufacture. 